
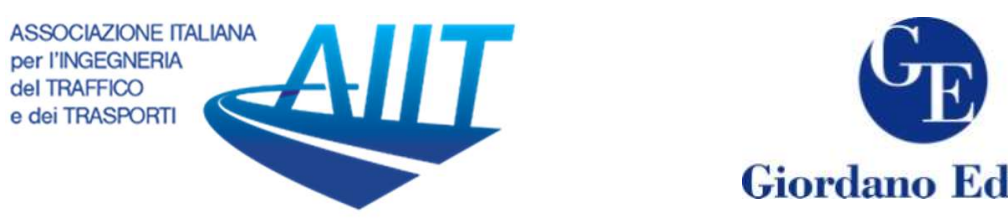

Giordano Editore

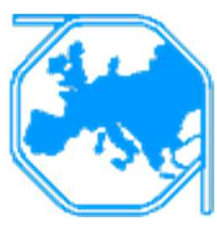

\title{
Impact of Sars-Cov-2 virus on Maritime Traffic in the Port of Ploce
}

\author{
Tatjana Stanivuk ${ }^{1}$, Ladislav Stazic ${ }^{1}$, Jurica Batinovic ${ }^{1 *}$, Anamarija \\ Batinovic ${ }^{1}$ \\ ${ }^{1}$ University of Split - Faculty of Maritime Studies, Rudjera Boskovica 37, Split, Croatia
}

\begin{abstract}
The paper investigates the impact of the SARS-COV-2 virus pandemics on overall cargo operations, using the company Luka Ploce Ltd. as an example. Luka Ploce Ltd (Port of Ploce) is a joint venture for maritime transport services, port services, warehousing and freight forwarding. Company data from the period from 2016 to 2019 was analysed using the prognostic ARIMA model (1.1.1) in order to predict volume of the cargo operations in 2020. The prognostic model predicted average increase of the cargo transhipments close to $10 \%$. That prediction is compared with the actual results of the Luka Ploce Ltd for the first half of the 2020. The comparison is showing that there was a significant decrease of the transhipments of the cargo of almost $32 \%$, with some exceptions due to delay in deliveries and urgent supplies of medical equipment.
\end{abstract}

Keywords: Sars-Cov-2, Luka Ploce Ltd, Cargo operations, Cargo transhipments

\section{Introduction}

The history teaches us that the maritime affairs are an important segment in the development of any economy and have a strong impact on the overall economy of the country. SARS-COV-2 or COVID-19 for short is a new virus that has appeared and caused stoppage of the world economy in all segments. The COVID-19 virus pandemic that has been spreading around the world since 2020, in addition to affecting people's daily lives and lives, has affected the global economy and the economy (Barua, 2020), the scale of which is still unpredictable, and we are not yet sure what awaits us in the future. The first wave has passed, what the second will be no one is sure. Various measures are being taken and attempts are being made to save businesses, but will that be enough?

Since 2003, severe acute respiratory syndrome (SARS), caused by different viral agents, has been recognized as a clinical entity of great epidemiological concern, because it can be fatal. There are seven different coronaviruses known that possess the ability to

*Corresponding author: Jurica Batinovic (jbatinov@pfst.hr) 
infect human cells; some of them cause mild upper respiratory symptoms, and others are potentially fatal. SARS-CoV-2 or COVID-19 is a coronavirus known to cause severe respiratory disease (Martinez - Rojas et al., 2020).

Coronaviruses are enveloped, positive single-stranded large RNA viruses that infect humans, but also a wide range of animals. Coronaviruses were first described in 1966 by Tyrell and Bynoe (Tyrel and Bynoe, 1965), who cultivated the viruses from patients with common colds. Based on their morphology (Figure 2) as spherical virions with a core shell and surface projections resembling a solar corona, they were termed coronaviruses (Latin: corona $=$ crown) (Velavan and Meyer, 2020).

Animal shop in Wuhan is connected with the first occurrence of coronavirus. Due to researches that have been made the bats are possible origins of virus (Bulut and Kato, 2020).

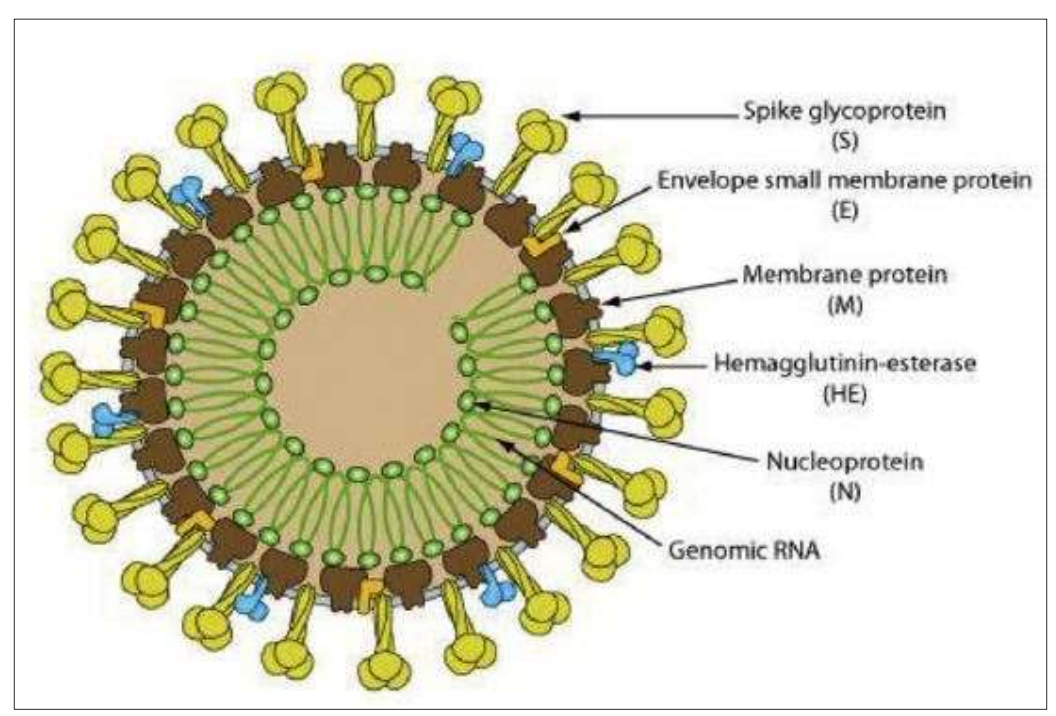

Figure 1: The Structure of SARS-CoV-2

Source: Mousavizadeh, Ghasemi, 2020.

Disease quickly spread around the world (Lancet, 2020) creating a pandemic, and more or less panic response from state officials. Various countries responded to the pandemic differently, some of countries imposed complete lockdown while some other countries introduced more lenient measures. In some cases, swiftly evolving pandemic caused panics (Hasöksüz et al., 2020), due to the lack of the proper information.

Today, $80 \%$ of the world's international maritime trade is carried out via sea and is therefore the foundation of many national economies, so it is not surprising that only a small change can shake the market and create a threat to the economy. Depending on the nature of the changes, maritime trade depends on various factors such as socio-economic changes, regulations, piracy or changes in the cultural, political or environmental environment (March, 2021). Large quantities of cargo transported via sea every day due to relatively cheap prices compared to other modes of transport are an important component of world trade and economy, therefore they give shipping and shipping great importance in the field of infrastructure development and employment (Jugović, et al., 2015).

The response of the large number of countries to the first wave of the pandemics was a lockdown. The lockdown (Figure 2) led to a decline of the production and consummation 
of goods and consequently in reduction in travel and trade. That caused a broad impact in various areas of life on the global scale as well as in local communities.

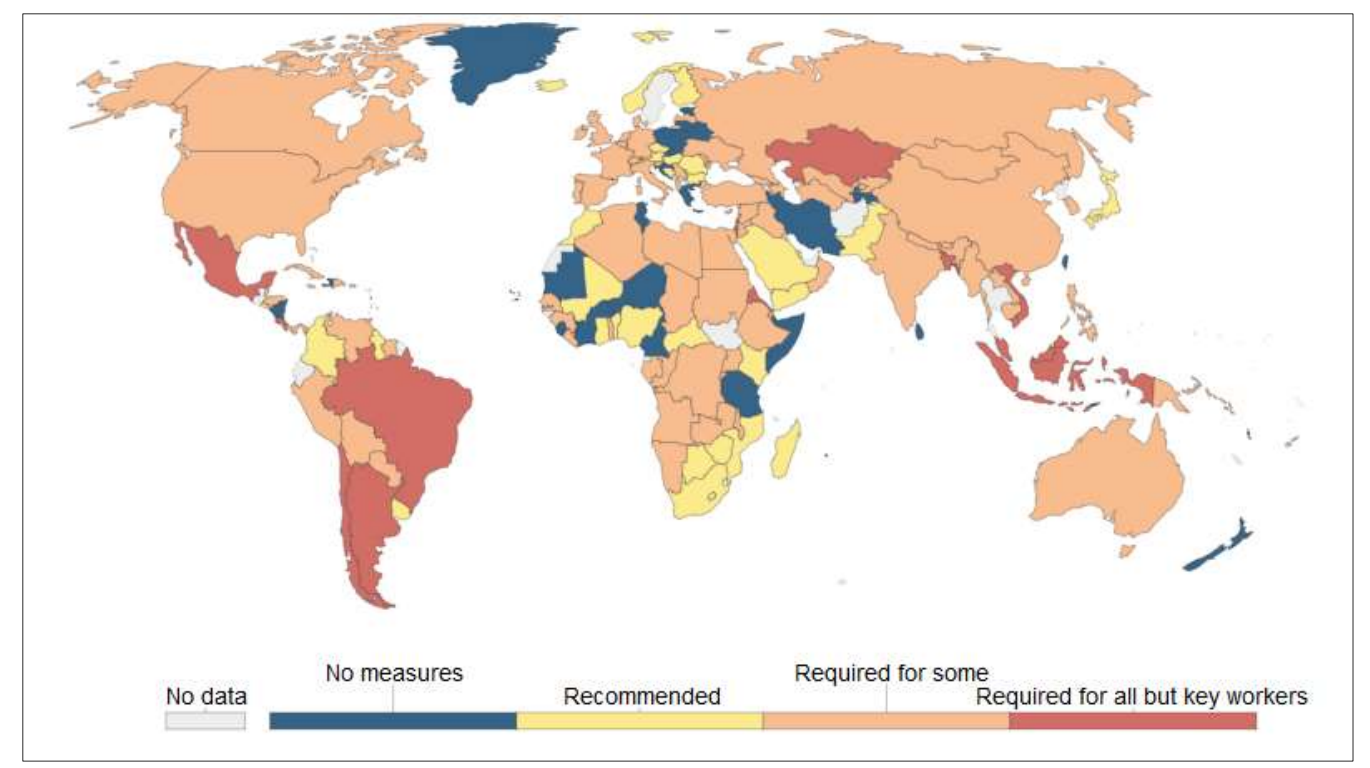

Figure 2: Workplace closures during the COVID-19 pandemic Source: Hale et al., 2020.

Due to its problems and dependence on the world market, the maritime and maritime industry in the COVID-19 pandemic has directly affected the financial situation of many shipping companies, bringing negative trends in the world stock market and thus directly affecting the commercial strategy of many maritime countries such as Greece, Singapore, Cyprus, etc.... (Nektarios et al., 2020). The SARS-COV pandemic called COVID-19 has tested the strength of maritime routes that are important for world trade connectivity. Great growth occurred in the medical industry, which due to the need and demand for drugs, vaccines and medical products recorded a growth of $116 \%$, while the global trade pandemic COVID-19 caused a decline of 5\% for the first three months of 2020 . The beginning of 2020 was marked by a negative trend in all industries due to falling market prices, rising unemployment, declining world trade and the economy. This trend was most reflected in ports that are important for container routes where a decline of $5 \%$ was recorded. The decline in container traffic in ports has resulted in low demand for container ships and non-utilization of full vessel capacity (Charłampowicz, 2021).

With the entry into the World Trade Organization (WTO) at the beginning of the 20th century, container traffic in the Chinese market increased, recording a growth of $10 \%$ in 2003 , then growth of $14 \%$ in 2019 . Given that China's industry is based on $18 \%$ gas, $16 \%$ crude oil and $20 \%$ chemicals, China gained a competitive advantage in the market during this period and thus became a major intermediary in container transport. The rapid spread of the new virus has left its mark on the global market, which has reduced the demand for goods from China and thus the demand for crude oil from the standard 3.4 billion tons of miles per day in 2019 decreased to almost 0 (Arifin, 2020).

The virus pandemics affected shipping industry; many shipping companies are closing down because their business has stumbled as well as their sources of financing. The industry, transporting $75 \%$ of all goods, has seen a drop in fares and low oil prices (Hale et al., 2020). 
Due to the improvement of ships throughout history, transportation costs have been shown to be around $0.5 \%$ of the price of oil, while at the time of the pandemic they increased to $4.5 \%$ due to a dramatic increase in costs and macroeconomic factors. Transport costs together with macroeconomic factors, in addition to freight, also had a significant impact on political and social events. (Nektarios et al., 2021), (Unctad, 2020) Oil transport becomes obsolete; many tankers become floating oil storage with nowhere to go (Review of Maritime Transport, 2020). Overall, the quantities of cargo transported are significantly reduced, creating the surplus ship space and a fall in the prices of shippers' shares (Hale et al., 2020). Cargo tonnage locked in tankers dropped from approximately 45 million dwt to 30 million dwt, while the number of tankers storing crude oil fell from 83 vessels to 56 vessels in period from end of April to end of May 2020 (Review of Maritime Transport, 2020).

According to European Maritime Safety Agency (EMSA), the impact of the COVID19 pandemics is visible in decline of the number of ships calls at EU ports. The number declined by $17.1 \%$ in the first 27 weeks of 2020 (European Maritime Safety Agency, 2020). Also, according to EMSA, "the most affected countries are Croatia, France, Iceland, Portugal and Spain” (European Maritime Safety Agency, 2020).

Long and developed coast providing natural protection for vessels and settlements and close connection with inland areas caused formation of important sea ports such as Rijeka, Zadar, Split, Dubrovnik, etc. One of the busiest sea ports in the Croatia is the Port of Ploce (Figure 3).

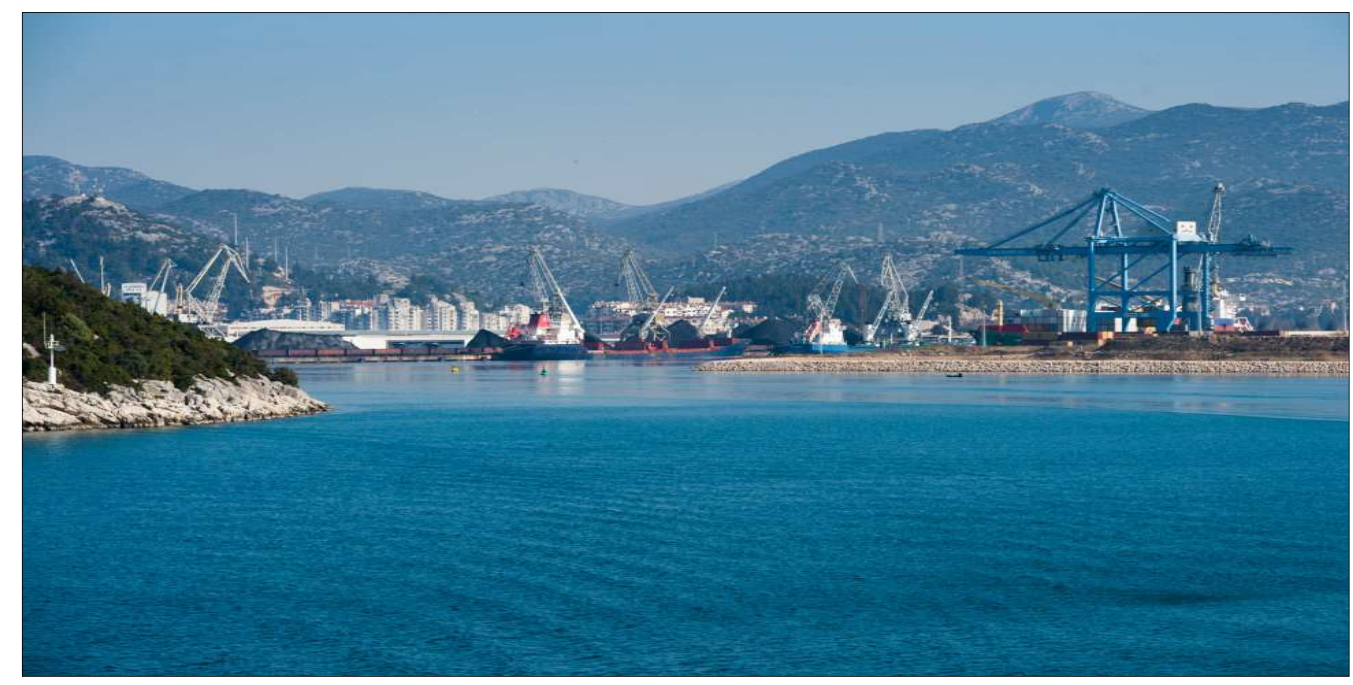

Figure 3: Port of Ploce

Source: Direktno.hr, 2018.

It is located in the middle of the Adriatic $\left(43^{\circ} 02^{\prime} \mathrm{N} ; 17^{\circ} 26^{\prime} \mathrm{E}\right)$, between cities and ports of Split and Dubrovnik. It is one of the main strategic Croatian ports with excellent transport connections and a favourable geostrategic position (Dundović et al., 2005), (Carević, 2017), (Marina, 2011), creating it a link between the Adriatic (the Mediterranean) and Central Europe.

The favourable geostrategic position of the port of Ploce made the port the only exit port of its natural hinterland, primarily for neighbouring Bosnia and Hercegovina. The river valleys of the Neretva, Bosnia and Vrbas represent an important transversal transport 
corridor across the Dinarides. The traffic route Ploce - Sarajevo - Samac - Osijek towards Hungary, which intersects with important longitudinal routes (like Istanbul - Sofia Beograd - Zagreb - Vienna), is especially important. Known as VC, this route connects Eastern Croatia with Dalmatia, and Hungary with Bosnia and Herzegovina, the Adriatic Sea and the Port of Ploce. It is important to note that the $\mathrm{X}$ - corridors pass through the Republic of Croatia; X, XA, VB, VII and their connections (Figure 4) which are important for connecting transport hubs across Europe and the Balkans and the Mediterranean Sea. For the port of Ploce, the further development of the Adriatic - Ionian route is of great importance. Due to its position and stable long-term business, it greatly contributes to local communities and the southern region of the Republic of Croatia. Since its foundation, the Port of Ploce has been a cargo and passenger port. Although with fewer oscillations, there is a constant increase in both freight and passenger traffic in the last twenty years (Dundović et al., 2005), (Carević, 2017), (Marina, 2011).

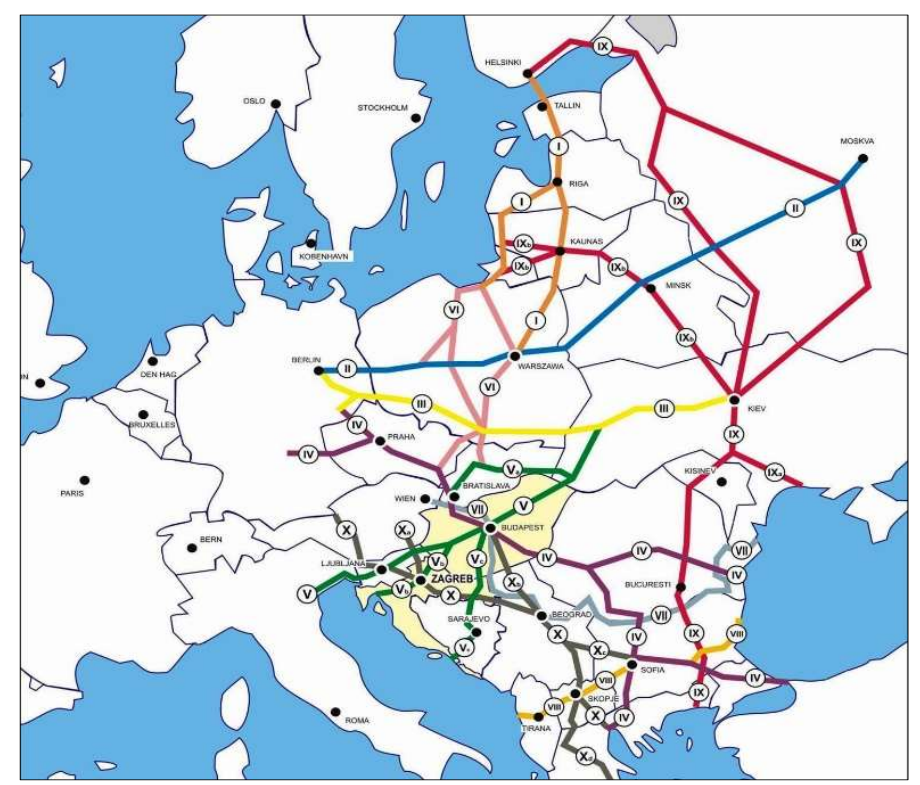

Figure 4: European Corridors

Source: MMPI, 2021.

The largest part of container transport in the Republic of Croatia passes through the port of Ploce and the port of Rijeka. Through further investment in their infrastructure, transhipment capacity expectations for the year 2020 for the Port of Ploce were high; analysts expected a further increase in freight and passenger traffic according to studies performed (Kolanović et al., 2015).

EMSA stated (European Maritime Safety Agency, 2020) that Croatia is one of the most affected countries in decline of the number of ships calls. Following that statement, the purpose of this paper is to investigate and determine the effect of the COVID-19 pandemics on the operations of the Port of Ploce, which is supposed to be serious (Rogotin, 2020). By analysing the operations of the Port of Ploce during the period from 2016 to 2019 and using mathematical tools based on data, an operation forecast for the first half of 2020 was made. 
ARIMA model as a mathematical tool is used to analyse time series (Figure 5). The ARIMA Process is widely used and recognised as a tool for the analysing various data (Benvenuto et al., 2020), (Contreras et al., 2003).

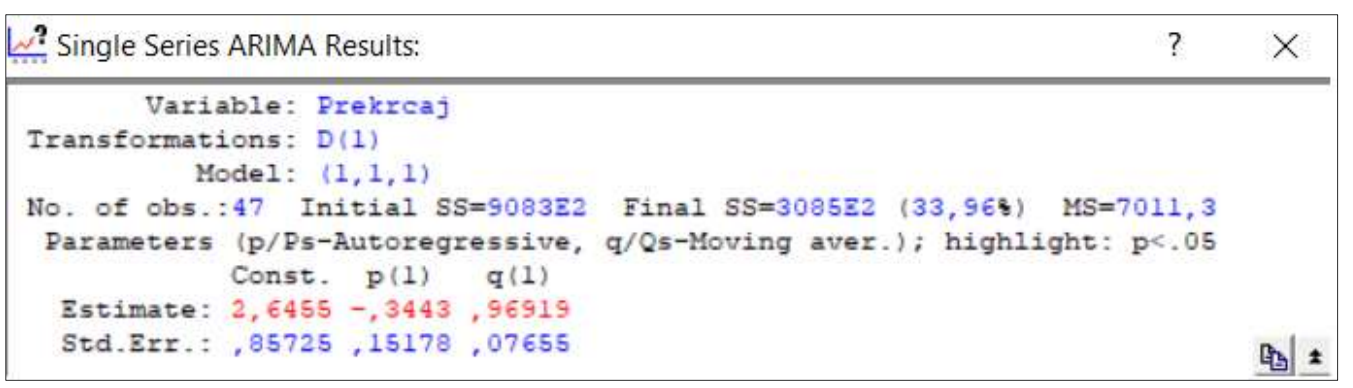

Figure 5: ARIMA model Application

\section{Traffic analysis and predictions}

The unconsolidated financial reports of Port of Ploce Ltd for the first quarter of 2020 show decline of series of parameters, as regards to last year first quarter. By comparing data from 2019 to 2020 traffic amount decreased from 803.5 thousand to only 550 thousand tons of goods, which makes traffic decline of $31.54 \%$. If considering sale of services incomes, which makes a decrease in revenues from services from 30.62 million HRK to 23.58 million HRK ( $1 €=7.5848$ HRK), decline of $22.99 \%$ is recorded. As regarding to calculation of total costs, the amount of 27.09 million HRK is recorded and the costs are $2.8 \%$ higher. Communal charges record the highest growth amongst the costs; they record the growth of $41.23 \%$. By application of IFRS 16, i.e., International Financial Reporting Standards Foundation as regards to period of previous year, calculation of amortization records growth of $20 \%$, while accrued interests record growth of 31\% (Rogotin, 2020), (DZS, 2020).

Table 1: Cargo traffic in kilotons during the period from 2016 to 2019

\begin{tabular}{lcccc}
\hline Month & 2016 & 2017 & 2018 & 2019 \\
\hline January & 182.37 & 212.35 & 297.33 & 307.48 \\
February & 242.02 & 278.86 & 177.47 & 143.56 \\
March & 154.19 & 268.32 & 180.43 & 352.62 \\
April & 284.75 & 221.59 & 459.54 & 465.17 \\
May & 218.51 & 242.55 & 191.29 & 197.96 \\
June & 203.92 & 306.64 & 261.92 & 329.21 \\
July & 230.30 & 197.70 & 221.75 & 366.96 \\
August & 307.52 & 361.10 & 150.14 & 404.32 \\
September & 159.52 & 340.08 & 325.59 & 116.81 \\
October & 349.23 & 222.28 & 205.83 & 385.35 \\
November & 206.63 & 375.17 & 400.86 & 218.19 \\
December & 141.88 & 168.35 & 281.17 & 271.71 \\
\hline
\end{tabular}

Figure 6 presents graphic results of the Table 1, creating an average value line that shows constant growth of traffic in Port of Ploce during the analysed period. The 
continuation of line in 2020 shows further expected growth. Blue line shows realized turnover while black line presents linear tendency.

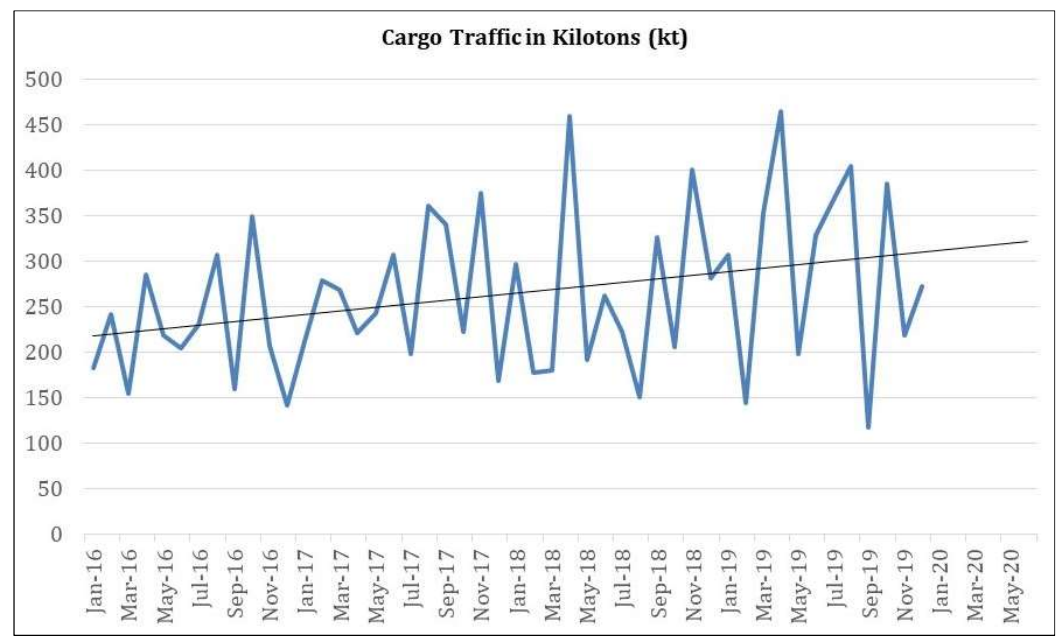

Figure 6: Prediction of traffic by average value line

The programmed projection of traffic movement in the port of Ploce for first six months of 2020 using the arithmetic mean is given in Table 2 .

Table 2: Arithmetic mean of freight traffic forecast for the port of Ploce for the period from January 2020 to June 2020 made using the program

\begin{tabular}{lccccccc}
\hline Month & January & February & March & April & May & June & Total \\
\hline Estimate (kt) & 312,19 & 314.66 & 317.15 & 319.65 & 322.18 & 324.73 & 1910.56 \\
\hline
\end{tabular}

ARIMA model calculates arithmetic mean and specific characteristics for each month, represented as deviation and variation. The model enabled more precise insight into the traffic transactions by months for required years by which the data is divided in Tables.

Table 3: Descriptive statistic of transhipment by months for analysed period from January 2016 to December 2019

\begin{tabular}{lccc}
\hline Month & Average traffic $(\mathrm{kt})$ & Standard deviation $(\mathrm{kt})$ & $V(\%)$ \\
\hline January & 249.88 & 53.70 & 21.49 \\
February & 210.48 & 53.00 & 25.18 \\
March & 238.89 & 78.09 & 32.69 \\
April & 357.76 & 106.97 & 29.90 \\
May & 212.57 & 20.00 & 9.41 \\
June & 275.42 & 47.86 & 17.38 \\
July & 254.18 & 66.20 & 26.05 \\
August & 305.77 & 96.17 & 31.45 \\
September & 235.50 & 98.63 & 41.88 \\
October & 290.67 & 77.89 & 26.80 \\
November & 300.21 & 88.37 & 29.43 \\
December & 215.78 & 61.47 & 28.49 \\
\hline
\end{tabular}


Table 3 presents that between the analysed years on May was recorded the lowest oscillation ( $\mathrm{V}=9.41 \%$ ) with average realized turnover of 212.57 kilotons.

Standard deviation is the average deviation from the arithmetic mean is a measure that shows the stratification of data within a set and is shown as the average deviation from the average in a given amount. The result of the standard deviation in this paper was obtained by taking each month separately within the analysed period, e.g., all January, then all February until the last month of the year (Tadić, 2017), (Hrvatska enciklopedija, 2021).

Table 4: Descriptive statistics of cargo traffic by years for analysed period from January 2016 to December 2019

\begin{tabular}{lccc}
\hline Year & Average traffic $(k t)$ & Standard deviation $(k t)$ & $V(\%)$ \\
\hline 2016 & 223.40 & 61.20 & 27.40 \\
2017 & 266.25 & 64.41 & 24.19 \\
2018 & 262.78 & 91.31 & 34.75 \\
2019 & 296.61 & 103.84 & 35.01 \\
\hline
\end{tabular}

Average values had tendency to grow in every following year (Table 4), i.e., it led to goods traffic growth and growth of oscillation level between observed months as it led to growth of variation coefficient value.

Prediction estimate model parameters are presented in the Table 5 and are used for calculation using the ARIMA model.

Table 5: Prediction estimate model parameters for analysed period from January 2016 to December 2019

\begin{tabular}{rcccc}
\hline & Parameter & Error & $t$ & $p^{*}$ \\
\hline$\mu=$ & 2.65 & 0.86 & 3.09 & 0.003 \\
$\mathrm{p}(1)=$ & -0.34 & 0.15 & -2.27 & 0.028 \\
$\mathrm{q}(1)=$ & 0.97 & 0.08 & 12.66 & $<0.001$ \\
\hline
\end{tabular}

According to estimation model, transhipment estimation is made for first six months of 2020 .

Table 6: ARIMA prediction of cargo traffic for Port of Ploce for the period from January 2020 to June 2020

\begin{tabular}{lccccccc}
\hline Month & January & February & March & April & May & June & Total \\
\hline Estimate (kt) & 334.23 & 316.26 & 326.00 & 326.20 & 329.69 & 332.05 & 1964.44 \\
\hline
\end{tabular}

\section{Discussion}

Results of the transhipments of the cargo in the Port of Ploce for the first half of the 2020 were published (Luka Ploce Ltd., 2020) and are presented in the Table 7 and Figure 7. 
Table 7: Realized cargo traffic for Port of Ploce for the period from January 2020 to June 2020

\begin{tabular}{lccccccc}
\hline Month & January & February & March & April & May & June & Total \\
\hline Realized (kt) & 82.39 & 363.68 & 104.14 & 202.88 & 352.99 & 232.49 & 1338.57 \\
\hline
\end{tabular}

By using the estimation model for January, estimated traffic counts 334.23 thousand tons of transhipments cargo, while realizing 82.39 thousand tons, i.e., $24.65 \%$ of planned; the decline of $75.35 \%$ is recorded. In February 2020 realized turnover counts to 363.68 thousand tons, while planned was 316.26 thousand tons. The reason for that is arrival of late deliveries from January so realized turnover of $14.99 \%$ is higher than expected.

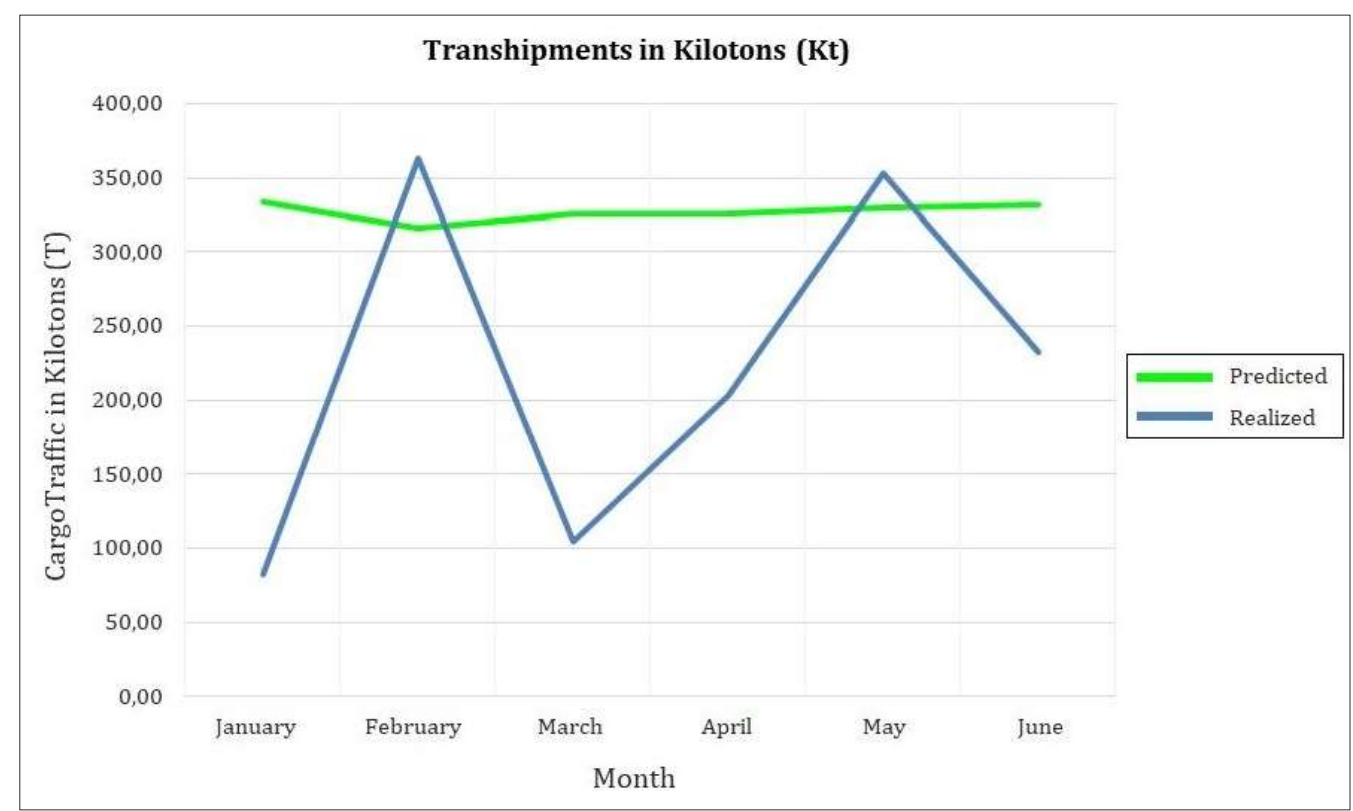

Figure 7: Predicted VS Realized transhipments

In March, there were 104.14 thousand tons of transhipments cargo recorded, which $31.94 \%$ of planned value is, the decline of $68.08 \%$ is recorded. Business volume continued lower than expected in April as well, the planned transhipments were 326.20 thousand tons, while the realized is 202.88 thousand tons. In May, realized turnover counted to 352.99 thousand tons, i.e., $7.07 \%$ more than expected, the reason of that is found in late deliveries from previous months and reduced volume of ongoing month, as well as delivery of COVID related medical supplies. So as a consequence of COVID-19, there has been growing instability in deliveries and the decline of observed port's business volume.

In June, realized turnover was $29.98 \%$ lower than expected. When looking aggregated data for the first six months, the expected traffic was 1964.44 thousand tons, while the realized turnover is 1338.57 thousand tons, which presents decline of $31.86 \%$. 


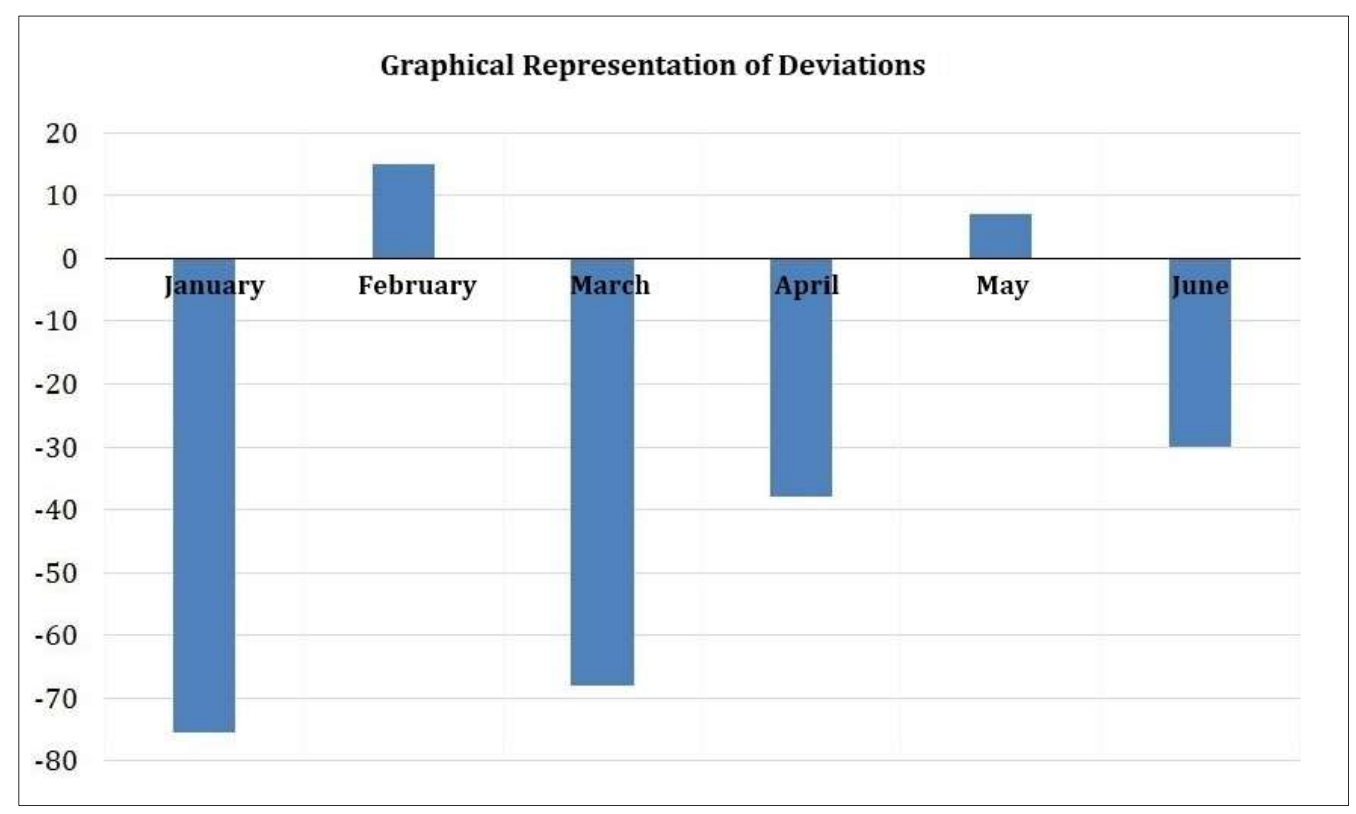

Figure 8: Deviations from estimated in percentages

From the Figure 8 it is visible that there were 2 peaks, one in February and one in May when the realised turnover was a little bit higher than planned, while in other four months realisation was significantly lower, which is supported by information that the total profit should be $1964.44 \mathrm{kt}$, and the realised counts $1338.57 \mathrm{kt}$.

\section{Conclusion}

Considering its geographical position, natural and cultural heritage, Croatia is an extremely rich country. Natural beauty, indented coastline and distribution are just some of the factors that complement the image of a country that had great potential for economic growth before the pandemic. The crisis caused by the COVID-19 virus has consequently led to a slowdown in economic activity as well as problems in maritime transport, which in turn have affected the operations of the Port of Ploce. After the research, it was proven that due to COVID-19 the volume of business decreased, and due to delays in deliveries, there was a significant instability in supply, which was reflected through significant oscillations in the plan.

According to the estimated model, in the first half of 2020, a turnover of 1964.44 million tons of cargo was expected, while according to data from company Luka Ploce Ltd, the joint - stock company Port of Ploce realized 1338.57 million tons, which is $31.86 \%$ less than planned, which is indicative of external factor influence such as COVID-19. Of the six observed months, in four months the turnover was lower than expected, while in February and May the turnover be above expectations. The oscillations led to an apparent increase in turnover in March where it exceeded expectations; however, it was significantly lower in other months within the current year.

The decline in the transhipments volume created additional difficulties, financial plans were not met. The company had to adjust their financial plan to cope with reduced activity and reduced income. Expenditures are diminished and focused mainly on salaries and necessary investments, waiting for the situation to improve. Further reduction of activities or prolongation of this situation will finally affect job numbers and employment rate. 
Regional residents may be left without stable income from this company, the joint-stock company Port of Ploce will not be able to pay salaries or save jobs thanks to the negative trend of its current business ventures while also keeping the same number of workers on their payroll.

This future research may be the basis for further research on the impact of COVID-19 in the port of the plate. Based on the research will be shown the recovery time, or the time of returning to "normal".

\section{References}

Barua, S. (2020) "Understanding Coronanomics: The economic implications of the coronavirus (COVID-19) pandemic", University Library of Munich, Germany, from: https://mpra.ub.uni-muenchen.de/99693/1/MPRA_paper_99693.pdf, retrieved on October 8th, 2020.

Barua, S. (2020) "Understanding Coronanomics: The economic implications of the coronavirus (COVID-19) pandemic", University Library of Munich, Germany, from: https://mpra.ub.uni-muenchen.de/99693/1/MPRA_paper_99693.pdf, retrieved on October $8^{\text {th }}, 2020$.

Martinez - Rojas, M.A., Vega - Vega, O., Bobadilla, N.A. (2020) "Is the kidney a target of SARS-CoV-2?", American Journal of Physiology - Renal Physiology, Volume 318 (6). $1454-1462$.

Tyrrell, D. A. J., \& Bynoe, M. L. (1965) "Cultivation of a novel type of common - cold virus in organ cultures", British medical journal, 1(5448), 1467.

Velavan, P.T., Meyer, G.C. (2020) "The COVID-19 epidemic", Tropical Medicine and International Health, Volume 25 (3). 278 - 280.

Bulut, C., Kato, Y. (2020) “Epidemiology of COVID-19”, Turkish Journal of Medical Sciences - Academic Journals, Volume 50. 563 - 570

Lancet, T. (2020) "COVID-19: fighting panic with information", Lancet, London, England, 395(10224), 537.

Hasöksüz, M., Kiliç, S., Saraç, F. (2020) "Coronaviruses and SARS-COV-2”, Turkish Journal of Medical Sciences - Academic Journals, Volume 50 (3). 549 - 556

Mousavizadeh, L., \& Ghasemi, S. (2020) "Genotype and phenotype of COVID-19: Their roles in pathogenesis", Journal of Microbiology, Immunology and Infection, March 2020, doi: 10.1016/j.jmii.2020.03.022

Hale, T., Webster, S., Petherick, A., Phillips, T. and Kira, B. (2020) "Oxford COVID-19 Government Response Tracker", from: https://www.bsg.ox.ac.uk/research/researchprojects/oxford-covid-19-government-response-tracke, retrieved on October $2^{\text {nd }}, 2020$.

European Maritime Safety Agency (2020) "COVID-19 impact on shipping", from: http://emsa.europa.eu/news-a-press-centre/covid19-impact.html, retrieved on October $2^{\text {nd }}, 2020$.

Dundović, Č., Kesić, B., \& Kolanović, I. (2005) “Značenje i uloga izgradnje prometnih koridora u razvitku luke Ploče", Pomorski zbornik, Volume 43(1), 113 - 130.

Carević, M. (2017) "Luka Ploče doctoral dissertation", University of Dubrovnik, Department of Maritime Transport.

Marina, K. J. B. (2011) "The development of the port of Ploče", $3^{\text {rd }}$ International Maritime Science Conference - IMSC 2011.

Direktno.hr (2018) "Havarija u luci Ploče, otežana opskrba naftnim derivatima u Dalmaciji", from: https://direktno.hr/domovina/havarija-u-luci-ploce-otezana-opskrbanaftnim-derivatima-u-dalmaciji-130508/, retrieved on October $6^{\text {th }}, 2020$. 
Curić, Z. (1993) "Prometnogeografsko značenje luke Ploče”, Hrvatski geografski glasnik, Volume 55 (1). 191 - 201.

Rogotin (2020) "Neto gubitak Luke Ploče 3.51 milijun kuna", from: http://www.rogotin.hr/2020/06/02/neto-gubitak-luke-ploce-351-milijun-kuna, retrieved on October $6^{\text {th }}, 2020$.

Benvenuto, D., Giovanetti, M., Vassallo, L., Angeletti, S., \& Ciccozzi, M. (2020) "Application of the ARIMA model on the COVID-2019 epidemic dataset", Data in brief, 105340.

Contreras, J., Espínola, R., Nogales, F. J., Conejo, A. J. (2003) "ARIMA Models to Predict Next - Day Electricity Prices", IEEE Transactions on Power Systems, Volume 18 (3), $1014-1020$

Luka Ploce Ltd. (2020) "Traffic in the Port of Ploce", from: https://www.lukaploce.hr/investitori/financijska-izvjesca/\#kvartalna-financijska-izvjesca, retrieved on October $2^{\text {nd }}, 2020$.

March, D., Metcalfe, K., Tintoré, J., Godley, B. J. (2021) “Tracking the global reduction of marine traffic during the COVID-19 pandemic", Nature Communications, Volume 12, 2415, from: https://doi.org/10.1038/s41467-021-22423-6, retrieved on July $8^{\text {th }} 2021$.

Charłampowicz, J. (2021) "Maritime container terminal service quality in the face of COVID-19 outbreak", Scientific Journal of Maritime Research, Volume 35 (1), 93-99, from: https://doi.org/10.31217/p.35.1.10, retrieved on July $9^{\text {th }} 2021$.

Jugović, A., Komadina N., Perić Hadžić, A. (2015) "Factors influencing the formation of freight rates on maritime shipping markets", Scientific Journal of Maritime Research, Volume 29 (1), 23-29, from: https://hrcak.srce.hr/140203, retrieved on July $9^{\text {th }} 2021$.

Nektarios A. Michail, Kostis D. Melas (2020) "Shipping markets in turmoil: An analysis of the Covid-19 outbreak and its implications", Transportation Research Interdisciplinary Perspectives, Volume 7, from: https://doi.org/10.1016/j.trip.2020.100178, retrieved on July $9^{\text {th }} 2021$.

Arifin, M. D. (2020) "Impacts of Coronavirus COVID-19 on the Global Shipping and Maritime Industry in Indonesia and How to Overcome the Coronavirus Outbreak: Based on WHO and IMO Recommendations", Jakarta, from: https://doi.org/10.31219/osf.io/crgv3, retrieved on July $8^{\text {th }} 2021$.

Nektarios, A. M., Konstantinos D. M. (2021) "COVID-19 and the Energy Trade: Evidence from Tanker Trade Routes", Faculty of Business and Economics, Metropolitan College, Thessaloniki, Greece.

Kolanović, I., Grgas-Oštro, A., Dundović, K. (2015) “Ocjena i tendencije razvitka prekrcajnih kapaciteta kontejnerskih terminala luke Rijeka, Ploče i Kopar", Zbornik Veleučilišta u Rijeci, Volume 3 (1), 196-206, from: https://doi.org/10.31784/zvr.3.1.15, retrieved on July $8^{\text {th }} 2021$.

Tadić, Tvrtko (2017) “Aritmetičke sredina i standardna devijacija”, Poučak, Volume 18 (69), 10-24, from: https://hrcak.srce.hr/189779, retrieved on July 10 2021.

Hrvatska enciklopedija (2021) "Standardna devijacija", Leksikografski zavod Miroslav Krleža, from: http://www.enciklopedija.hr/Natuknica.aspx?ID=57758, retrieved on July $10^{\text {th }} 2021$.

UNCTAD (2020) "Review of Maritime Transport 2020", UNCTAD - Palais des Nations, 8-14, Av. de la Paix, 1211 Geneva 10, Switzerland, from: https://unctad.org/webflyer/review-maritime-transport-2020, retrieved on July $8^{\text {th }} 2021$. 
European Transport $\backslash$ Trasporti Europei (2021) Issue 82, Paper n ${ }^{\circ}$ 7, ISSN 1825-3997

UNCTAD/RMT (2020) "Review of Maritime Transport 2020", United Nations Publications 300 East $42^{\text {nd }}$ Street New York, New York 10017, from: https://unctad.org/webflyer/review-maritime-transport-2020,

DZS (2020) “Traffic in seaports first quarter of 2020", Published by the Croatian Bureau of Statistics, Zagreb, from: https://www.dzs.hr/Hrv_Eng/publication/2020/05-0102_01_2020.htm, retrieved on July $8^{\text {th }} 2021$.

MMPI (2021), "European Corridors", Ministry of the Sea, Transport and Infrastructure of the Republic of Croatia, from: https://mmpi.gov.hr/print.aspx?id=3246\&url=print, retrieved on July $10^{\text {th }} 2021$. 